\title{
The clinical significance of anticardiolipin antibody levels in patients with acute myocardial infarction: a regional study
}

\author{
Faruk Ertaș ${ }^{1}$ Öznur Can², Halit Acet ${ }^{1}$, Mert Ozbakkaloglư \\ ${ }^{1}$ Department of Cardiology, Medicine Faculty, Dicle University, Diyarbakir, Turkey \\ ${ }^{2}$ Department of Internal Medicine, Tepecik Education and Research Hospital, İzmir, Turkey
}

Postep Kardiol Inter 2013; 9, 4 (34): 328-331

DOI: $10.5114 /$ pwki.2013.38859

\begin{abstract}
Introduction: Acute myocardial infarction (AMI) will probably remain the most important cause of death over the next decades. Traditional risk factors of atherosclerosis could not exactly explain the development of acute coronary events such as AMI. Antiphospholipid antibody syndrome is a disorder characterized by the development of arterial and venous thrombosis.

Aim: In this study, we investigated the relations between acute myocardial infarction and anti-phospholipid antibody syndrome in our population representing Aegean Region people characteristics.

Material and methods: One hundred patients with acute myocardial infarction were consecutively included in the study (group I) and one hundred age and sex matched people with similar risk factors were enrolled in the study as a control group (group II). Anticardiolipin antibody $(\mathrm{aCL}) \mathrm{IgM}$ and IgG levels were measured in the two groups. Levels of $\mathrm{aCL} / \mathrm{gG} \geq 48 \mathrm{U} / \mathrm{ml}$ and/or aCL $\mathrm{lgM}$ $\geq 44 \mathrm{U} / \mathrm{ml}$ were accepted as positive and significant.

Results: In patients with acute myocardial infarction, 5 patients (5\%) had positive IgM levels and 8 patients (8\%) were found to have positive IgG levels. All cases in the control group had negative aCL IgM and IgG antibody levels. These results were accepted as significant for both $\mathrm{aCL}$ antibodies between patients and controls $(p<0.001)$.

Conclusions: We concluded that $\mathrm{aCL}$ antibody levels are also higher in a small proportion of patients with acute myocardial infarction than controls in our region, also, and these results suggest that there may be an immune stimulus in the pathogenesis of acute coronary events.
\end{abstract}

Key words: acute coronary syndrome, anticardiolipin antibodies, antiphospholipid syndrome, thrombosis.

\section{Introduction}

Nowadays, coronary artery disease (CAD) has become the most important cause of death worldwide. The disease causes approximately $30 \%$ of all deaths in the world [1]. Despite considerable advances in diagnosis and treatment strategies, acute myocardial infarction (AMI) continues to be a major problem of public health worldwide [2]. Although in-hospital mortality rates of AMI have declined over the past decades with the invention of coronary care units, and fibrinolytic and interventional reperfusion therapies, pre-hospital mortality rates are still higher and the overall mortality rate is about $45 \%$ at present [3]. The disease is likely to remain the most important cause of death over the next decades. Traditional risk factors of atherosclerosis such as diabetes, smoking, hyperten- sion and hypercholesterolemia could not explain the development of acute coronary events such as AMI in the course of atherosclerotic coronary artery disease. Some triggering factors initiate coronary plaque fissuring, rupture and concomitant thrombosis. At this point, there are some gray zones that could not be explained completely. Endothelial dysfunction, inflammation, and vasospasm may explain this process in part. Antiphospholipid antibody syndrome is an autoimmune disease characterized by increased tendency of arterial and venous thrombosis, recurrent spontaneous abortions, thrombocytopenia and circulating antiphospholipid antibodies such as anticardiolipin [4]. The association between acute myocardial infarction and antiphospholipid antibody syndrome has drawn attention and has been investigated by some researchers in different populations and regions of the

\section{Corresponding author:}

Faruk Ertaș, Department of Cardiology, Medicine Faculty, Dicle University, Diyarbakır, Turkey, tel.: 90412 2488001, fax: 90 412 2488002,

e-mail: farukertas@hotmail.com

Received: 25.03.2013, accepted: 10.07.2013. 
world. We considered that some regional and racial differences may be seen in this association.

\section{Aim}

Therefore, in this study, we investigated the relations between acute myocardial infarction and anti-phospholipid antibody syndrome in our population representing Aegean Region people characteristics.

\section{Material and methods}

In this study, because we planned to investigate the prevalence of primary antiphospholipid syndrome in patients with acute myocardial infarction in our region, the case-control study design was selected. The study was conducted in Tepecik Education and Research Hospital in collaboration with the departments of cardiology, Atatürk Education and Training Hospital. The study was approved by the Local Ethics Committee and informed consent was obtained from each patient.

One hundred patients with acute myocardial infarction were consecutively included in the study (group I) and one hundred age and sex matched people having similar risk factors and not having known coronary artery disease, diabetes or hypertension were enrolled in the study as a control group (group II). Patients having signs of infection, autoimmune disease and malignancy or taking any drugs affecting the levels of anticardiolipin $(\mathrm{aCL})$ antibodies (procainamide, quinidine, phenytoin, chlorpromazine, etc.) were excluded from the study. Anticardiolipin antibody levels were measured in two groups. Venous blood samples were drawn from the antecubital vein via a vacuum syringe after the patients were admitted to the coronary care unit with the diagnosis of acute myocardial infarction. Micro-enzyme-linked immunosorbent assay method was used with the device of Tektime 21001 (Organon, IL, USA) to measure anticardiolipin IgG and IgM levels. The levels of anticardiolipin IgG $\geq 48 \mathrm{U} / \mathrm{ml}$ and/or anticardiolipin lgM $\geq 44 \mathrm{U} / \mathrm{ml}$ were accepted as positive and significant according to the interpretation of the kit manual.

\section{Statistical analysis}

The statistical analysis was performed using SPSS for Windows version 15.0 (SPSS Inc Chicago, IL, USA). Continuous variables are expressed as mean \pm standard deviation and categorical variables are expressed in number and percentage. Student's $t$-test was used for the comparison of continuous variables and the $\chi^{2}$ or Fisher exact test was used for comparison of the categorical variables. A $p$ value of $<0.05$ was considered as significant.

\section{Results}

The characteristics of patients and controls and main results of the study are shown in Table 1 . In patients with acute myocardial infarction, the oldest patient was 82 years and the youngest one was 23 years. In the control group, the oldest patient was 79 and the youngest one was 25 years. In patients with acute myocardial infarction, 5 patients (5\%) had positive IgM levels, and 8 patients (8\%) were found to have positive IgG levels. All cases in the control group had negative $\mathrm{aCL}$ IgM antibody and negative $\mathrm{aCL}$ IgG antibody levels. These results were accepted significant for both $\mathrm{aCL}$ antibodies between patients and controls $(p<0.001)$. Of the patients with positive $\mathrm{aCL}$ IgM antibody levels, 2 were women (40\%) and 3 were men (60\%). The mean age was $67.00 \pm 12.1$ ranging between 50 and 81 . The patients having positive aCL IgM antibody had an average serum aCL IgM antibody level of 56.00 $\pm 7.33 \mathrm{U} / \mathrm{ml}$; the lowest one was $47.00 \mathrm{U} / \mathrm{ml}$ and the highest one was $66.00 \mathrm{U} / \mathrm{ml}$. Of the patients with positive $\mathrm{aCL}$ IgG antibody levels, 3 were women (37.5\%) and 5 were men (62.5\%). The mean age was $58.12 \pm 9.78$ ranging between

Table 1. Clinical characteristics of patients and controls and main results

\begin{tabular}{|c|c|c|c|c|c|}
\hline \multirow[t]{2}{*}{ Parameter } & \multicolumn{2}{|c|}{ Patients } & \multicolumn{2}{|c|}{ Controls } & \multirow[t]{2}{*}{ Value of $p$} \\
\hline & $n$ & $\%$ & $n$ & $\%$ & \\
\hline Age & \multicolumn{2}{|c|}{$59.18 \pm 12.17$} & \multicolumn{2}{|c|}{$57.50 \pm 10.24$} & 0.645 \\
\hline Gender & & & & & 0.750 \\
\hline Men & 74 & 74 & 72 & 72 & \\
\hline Women & 26 & 26 & 28 & 28 & \\
\hline Diabetes & 12 & 12 & 0 & 0 & $<0.001$ \\
\hline Hypertension & 31 & 31 & 0 & 0 & $<0.001$ \\
\hline CAD & 18 & 18 & 0 & 0 & $<0.001$ \\
\hline Hyperlipidemia & 49 & 49 & 48 & 48 & 0.887 \\
\hline Smoking & 50 & 50 & 32 & 32 & 0.010 \\
\hline Family history & 40 & 40 & 32 & 32 & 0.239 \\
\hline Obesity & 22 & 22 & 32 & 32 & 0.111 \\
\hline aCL IgM positivity & 5 & 5 & 0 & 0 & $<0.001$ \\
\hline aCL IgG positivity & 8 & 8 & 0 & 0 & $<0.001$ \\
\hline
\end{tabular}


A

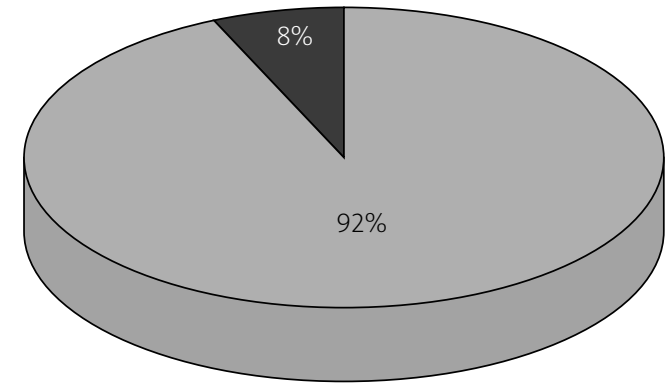

$\mathrm{aCL} \lg G$
B

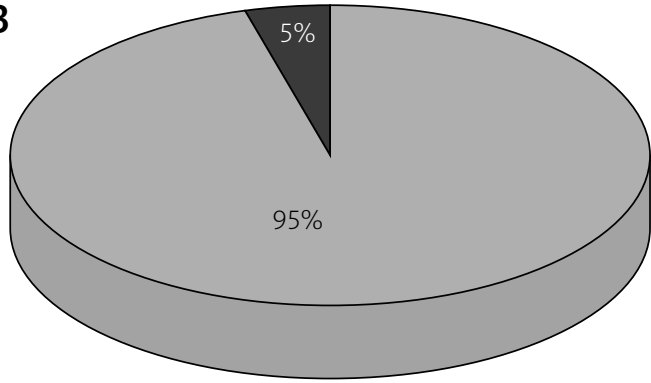

$\mathrm{aCL} \lg M$

$\square$ Negative

Positive

Fig. 1. Distribution of $\mathrm{aCL} \lg G(\mathbf{A})$ and $\mathrm{aCL} \lg M(\mathbf{B})$ positivity in patients with acute myocardial infarction

23 and 80 years. The patients having positive aCL IgG antibody had an average serum lgG level of $58.12 \pm 9.78 \mathrm{U} / \mathrm{ml}$; the lowest one was $49.00 \mathrm{U} / \mathrm{ml}$ and the highest one was $80.00 \mathrm{U} / \mathrm{ml}$.

\section{Discussion}

This study reveals that a relatively small percentage of patients with acute myocardial infarction have higher levels of $\mathrm{aCL}$ IgM and IgG antibodies than age and sex matched controls with similar risk factors for coronary artery disease in our region, also. In the normal population, seropositivity of aCL antibodies is seen in 0 to $7.5 \%$ but it is seen in 6 to $47 \%$ of survivors of acute myocardial infarction and prevalence has been increasing with increased age $[5,6]$. Anticardiolipin antibodies bind to some cofactors with intrinsic anticoagulant activity such as protein $C$, protein $S$, annexin 5 and $\beta_{2}$ glycoprotein- 1 and may inhibit their activities [7]. In addition, aCL IgG antibodies increase platelet activation and thromboxane synthesis [8] and activate endothelial cells, which may cause endothelial dysfunction [9]. Therefore $\mathrm{aCL}$ antibodies may change anticoagulant system function and cause a tendency to venous and arterial thrombosis and recurrent thrombotic events such as acute myocardial infarction [10]. Transient elevations of $\mathrm{aCL}$ antibodies associated with drugs, infections and acute disease are not related to these changes, although chronically high levels of $\mathrm{aCL}$ antibodies may be connected with these catastrophic complications. Acute myocardial infarction occurs in $2.8 \%$ to $20 \%$ of antiphospholipid syndrome patients [11]. However, associations between aCL antibody elevations and recurrent thrombotic events have not been revealed clearly to date. There are many different reports on these associations worldwide, so there may be racial and regional differences influencing these relationships. The association between increased $\mathrm{aCL}$ antibodies and arterial and venous thrombosis was reported for the first time in 1983 [12]. In an Italian study, Gaeta et al. investigated the relationships between $\mathrm{aCL}$ antibodies and acute myocardial infarction in their popula- tion, but they found that $\mathrm{aCL}$ levels are not elevated in AMI patients, are not associated with in-hospital complications, and do not change the early stage of the disease [13]. Bili et al. investigated the association between $\mathrm{aCL}$ and recurrent cardiovascular events in a large population of post-infarction patients in the USA and found that elevated IgG aCL and low IgM aCL antibodies are independent risk factors for recurrent cardiac events in 1150 patients [14]. Patients with both elevated IgG aCL and low IgM aCL antibodies have the highest risk for recurrent coronary events [14]. In a Russian study, Logacheva et al. also reported that acute coronary syndromes are associated with marked immune alterations primarily with elevated levels of circulating immune complexes and anticardiolipin antibodies, and that these alterations may persist for 3 to 5 weeks after the first event and trigger recurrent coronary events and thrombotic complications after relief of clinical symptoms of an acute coronary event [15]. However, Erkkila et al. suggested that the titers of anticardiolipin antibodies did not differ among the patient groups including acute myocardial infarction, acute myocardial ischemia and stable coronary artery disease consisting of coronary artery bypass surgery and balloon angioplasty patients, and that neither of the $\mathrm{aCL}$ antibodies was associated with recurrent coronary events in a Finnish study [16]. Hughes and colleagues reported that $\mathrm{aCL}$ antibodies are higher in patients with angina and acute myocardial infarction than normal controls in a United Kingdom population [17]. Ranzolin et al. reported from Brazil that anticardiolipin antibodies are not independent risk factors for acute myocardial infarction [18]. From Spain, Seijas et al. stated that anticardiolipin antibodies are higher (12\%) in patients with acute myocardial infarction under 65 years than control cases (5\%) but not associated with post-infarction thrombotic events [19]. Phadke et al. also reported that there was no significant association between anticardiolipin antibody concentrations and either myocardial infarction or unstable angina in 467 patients [20]. Zuckerman et al., however, suggested that the presence of aCL antibody is a marker 
for increased risk of subsequent myocardial reinfarction and thromboembolic events after acute MI [21]. Gurlek et al. suggested that higher $\mathrm{aCL}$ antibody levels were not associated with mortality, reinfarction and the development of intracardiac thrombus but were related to higher rates of restenosis in acute coronary syndrome patients and also pulmonary emboli $[22,23]$. As a result, the debate on the associations between increased levels of $\mathrm{aCL}$ antibodies and acute cardiac events has been ongoing. Nowadays, $\mathrm{aCL}$ antibodies are not used as a marker in coronary risk stratification because of their heterogeneity, measurement differences and insufficiency and mixing of present proofs.

\section{Conclusions}

In this study, we concluded that $\mathrm{aCL}$ antibody levels are also higher in a small proportion of patients with acute myocardial infarction than controls in our region, and these results suggest that there may be an immune stimulus in the pathogenesis of acute coronary events. Increased $\mathrm{aCL}$ antibody levels may trigger new antigenic cascades and these may accelerate acute thrombotic events. In these patients, more intense anti-aggregant and anticoagulant treatment may be required.

\section{References}

1. Lopez AD, Mathers CD, Ezzati M, et al. (eds.). Global Burden of Disease and Risk Factors. World Bank, Washington 2006.

2. Antman EM, Braunwald E. ST-elevation myocardial infarction pathology, pathophysiology and clinical features. In: Libby P, Bonow RO, Mann DL, et al. (eds.) Braunwald's heart disease: a textbook of cardiovascular medicine. 8 ed. Saunders Elsevier, Philadelphia 2008; 1207.

3. Vivekananthan DP, Lauer MA. Acute myocardial infarction. In: Griffin BP, Topol EJ. Manual of cardiovascular medicine. 2 ed. Lippincot Williams \& Wilkins, Philadelphia 2004.

4. Levine JS, Branch DW, Rauch J. The antiphospholipid syndrome. N Engl J Med 2002; 346: 752-763.

5. Vaarala O, Manttari M, Manninen V, et al. Anticardiolipin antibodies and risk of myocardial infarction in a prospective cohort of middle-aged men. Circulation 1995; 91: 23-27.

6. Eber B, Kronberger-Schaffer $\mathrm{E}$, Brusee $\mathrm{H}$, et al. Anticardiolipin antibodies are no marker for survived myocardial infarction. Klin Wochenschr 1990; 68: 594-596.

7. Roubey RA. Mechanisms of autoantibody-mediated thrombosis. Lupus 1998; 7: 114-119.

8. Martinuzzo ME, Maclouf J, Carreras LO, et al. Antiphospholipid antibodies enhance thrombin-induced platelet activation and thromboxane formation. Thromb Haemost 1993; 70: 667-671.

9. Cuadrado MJ. Thrombosis in primary antiphospholipid syndrome: a pivotal role for monocyte tissue factor expression. Arthritis Rheum 1997; 40: 834-841.

10. Sheng Y, Kandiah DA, Krilis SA. Beta2-glycoprotein I: target antigen for antiphospholipid antibodies: immunological and molecular aspects. Lupus 1998; 7: 5-9.

11. Vaarala 0 . Antiphospholipid antibodies and myocardial infarction. Lupus 1998; 7: 132-134.
12. Harris EN, Gharavi AE, Boey ML, et al. Anticardiolipin antibodies: detection by radioimmunoassay and association with thrombosis in systemic lupus erythematosus. Lancet 1983; 2: 1211-1214.

13. Gaeta G, Lupoli S, Brancaccio V, et al. Anticardiolipin antibodies and early infarct of the myocardium. Cardiologia 1998; 43: 731-735.

14. Bili A, Moss AJ, Francis CW, et al. Anticardiolipin antibodies and recurrent coronary events: a prospective study of 1150 patients. Thrombogenic Factors, and Recurrent Coronary Events Investigators. Circulation 2000; 102: 1258-1263.

15. Logacheva IV, Leshchinskia LA, Zvorygin IA. Immunological characteristics of patients with acute coronary syndrome (unstable angina and acute myocardial infarction). Klin Med 1999; 77: 23-25.

16. Erkkila AT, Narvanen O, Lehto $S$, et al. Autoantibodies against oxidized low-density lipoprotein and cardiolipin in patients with coronary heart disease. Arterioscler Thromb Vasc Biol 2000; 20: 204-209.

17. Hughes JR, Davies JA. Anticardiolipin antibodies in clinical conditions associated with a risk of thrombotic events. Thromb Res 1998; 89: 101-106.

18. Ranzolin A, Bohn JM, Norman GL, et al. Anti-beta2-glycoprotein I antibodies as risk foctors for acute myocardial infarction. Arq Bras Cardiol 2004; 83: 141-144.

19. Seijas M, Martinez VC, Rivera A, et al. Prevalence of antiphospholipid syndrome in patients under 65 years of age with acute myocardial infarction. Rev Clin Esp 2001; 201: 118-121.

20. Phadke KV, Phillips RA, Clarke DT, et al. Anticardiolipin antibodies in ischaemic heart disease: marker or myth? Br Heart J 1993; 69: 391-394.

21. Zuckerman E, Toubi E, Shiran A, et al. Anticardiolipin antibodies and acute myocardial infarction in non-systemic lupus erythmatosus patients: a controlled prospective study. Am J Med 1996; 101: 381-386.

22. Gurlek A, Ozdil C, Pamir G, et al. Association between anticardiolipin antibodies and recurrent cardiac events in patients with acute coronary syndrome. Int Heart J 2005; 46: 631-638.

23. Gündoğdu F, Unlü Y, Bariș N, Arslan S. Antiphospholipid antibody syndrome leading to massive pulmonary embolism and sudden death. Turk Kardiyol Dern Ars 2008; 36: 467-469. 